\title{
The promotive effects of some natural extracts (algal, yeast and vermiwash) on vegetative characteristics and nutrients status of citrus lemon (Citrus aurantifolia) seedlings
} \author{
Y.A.T. Moustafa ${ }^{5}$ and Nagwa S. Zaid ${ }^{1}$ \\ ${ }^{1}$ Pomology Dept., National Research Centre, Cairo, Egypt. \\ ${ }^{2}$ Agricultural Microbiology Dept., National Research Centre, Cairo, Egypt. \\ ${ }^{3}$ Citrus Dept., Agriculture Research Centre, Egypt. \\ ${ }^{4}$ Fertilization Technology Dept., National Research Centre, Cairo, Egypt. \\ ${ }^{5}$ Central Lab for Aquaculture Research (CLAR), Egypt.
}

Nabil S. Mustafa ${ }^{1 \star}$, Ibrahim A. Matter ${ }^{2}$, Hanaa Refai Abdalla ${ }^{3}$, Mohamed F. El-Dahshouri ${ }^{4}$,

Accepted 18 March, 2019

\begin{abstract}
A huge amount of agricultural waste produced in agri-aquacultural farms could play a positive and important role in different aspects starting from decreasing rate of soil degradation till raising soil fertility besides maintaining activity and diversity of microorganism community in soil, thereby good and effective managing of recycling these agri-aquacultural wastes through utilizing these wastes in producing vermicompost and vermiwash may reflect in these positive impacts. Natural extracts (Algal, Yeast and Vermiwash) are considered as promising and ecofriendly foliar fertilization for vegetables and fruits. This study focused on short term evaluation and comparing three natural extracts: algal, yeast and vermiwash, as foliar fertilizers in citrus lemon (Citrus aurantifolia) seedlings. Vegetative growth parameters (leaf area, leaf fresh and dry weight) as well as leaf mineral content ( $\mathrm{N}, \mathrm{P}, \mathrm{K}, \mathrm{Ca}$ and $\mathrm{Mg}$ ) and chlorophyll were monitored in response to different concentrations of investigated foliar fertilizers. In addition, soil microbial activity was enzymatically estimated as a reflection of positive impact of tested natural extracts. Obtained results showed that foliar spraying with algal extract at $2 \%$ and yeast extract at $1 \%$ showed increased leaf fresh and dry weight of lemon seedlings. Foliar spraying of vermiwash at $10 \%$ as well as yeast extract at $2 \%$ promoted increase in leaf area. Vermiwash was superior in enhancing mineral contents in leaves compared with algal and yeast extract. Moreover microbial activity of rhizosphere will be affected by nutritional status of plants. Algal extract as foliar fertilization could enhance soil microbial activity due to plant root exudates. Vermiwash extract as well as yeast and algal extracts (as a natural extracts) could be safely recommended (in the same order) as foliar fertilizer to improve growth of citrus lemon seedlings and increase soil microbial activity.
\end{abstract}

Keywords: Citrus seedlings, Vermiwash, natural extracts, promotion growth, nutrient status, microbial activity.

${ }^{*}$ Corresponding author. E-mail: nabilhotline@yahoo.com.

\section{INTRODUCTION}

Citrus is one of the most important fruit crops in tropical and subtropical countries and is considered as the first economic fruit crop in Egypt (Abobatta, 2018). In old vally, production and quality of citrus certainly affected with excessive uses of chemical fertilizers, moreover these effects will reflected negatively on both of human 
health and environment (Nath and Singh, 2011). Under this critical situation, bio-organic fertilization of fruits especially citrus crops acquired the attention of researchers and farmers to compromise this problem and improve the quality of the final product. Also, foliar application may help in increasing up taking of organic fertilizers and reinforce its role in enhancing vegetative growth and physiological properties of plants (Palagani and Singh, 2017).

Yeast extract contains large amounts of essential minerals, vitamins $\left(B_{1}, B_{2}\right.$ and $\left.B_{6}\right)$, proteins and the natural plant hormones namely cytokinins. Application of yeast extract as foliar fertilizer is successfully able to promote growth and enhance final production of plants (Hashem et al., 2008; Marzauk et al., 2014). In addition to direct nutrients amendments via yeast extract, its cytokinins and auxin contents play a role in delay the aging of leaves through retardation the degradation of chlorophyll and enhancing proteins synthesis (Abou ElYazied and Maday, 2012). Moreover, yeast extract, considered bio-stimulant, canto enhance the yield of and fruit quality of several fruit trees (El-Sayed, 2013).

Microalgae as photosynthetic microorganisms are considered as an important source of nutrients and bioproducts (Matter et al., 2018). It could be cultivated in various aquatic environments, i.e. freshwater, marine water or even in pre-treated wastewaters (Eida et al., 2018). As a nutrient-rich biomass, foliar application of microalgal extract which contains some macro and micro nutrients, vitamins, polyamines as well as growth promoters, considered as an effective bio-fertilizer. Several studies showed that its foliar application enhanced leaf nutrient content, total chlorophyll, number of fruits per tree, yield and fruit quality (Abd El-Migeed et al., 2004; Abd-El-Moniem and Abd-Allah, 2008; Spinelli et al., 2009).

Vermiwash is a watery extract of nutrient-rich vermicompost which contains earthworms' secretions, macro and micronutrients, nitrogenous excretory products, amino acids, phenols, growth promoting hormones and essential enzymes. It could be applied in foliar spray with the objective of promote the increase of nutrients inside the plants and enhance your growth, besides have action as a biopesticide (Hatti et al., 2010; Kaur et al., 2015; Jandaik et al., 2015). Studies used vermiwash as foliar sprayed demonstrated yours ability to increase shoot and root weight as well as total dry weight of studied plants (Elumalai et al., 2013).

To the best of our knowledge, no available reports compared the three mentioned bioextracts as foliar fertilizers. Therefore, this short-term study aimed to investigate and evaluate yeast extract, microalgal extract as well as vermiwash as foliar fertilizer for citrus lemon (Citrus aurantifolia) seedlings. Vegetative growth and nutrition status of citrus lemon seedlings as well as microbial activities of its rizosphere were monitored in response to foliar fertilization using three concentrations of the natural extracts (algae, yeast and vermiwash).

\section{MATERIALS AND METHODS}

\section{Preparation of tested bioextracts}

\section{Yeast extract}

Appropriate amount of brewer's yeast (active dry Saccharomyces cerevisiae) was activated in water containing equal amount of sugar. The mixture was kept in dark warm place over night to allow vegetative growth of yeast. Dilution with water was performed to have a final cell density of $7.3 \times 10^{7} \mathrm{ml}^{-1}$. Water extract of yeast are obtained by repeated freezing and thawing yeast culture to disrupt cells (Barnett et al., 1990). Aqueous yeast extract was kept at $-20^{\circ} \mathrm{C}$ and thawed directly before use.

\section{Algal extract}

The commercial algal extract (oligo-x) was obtained from private company (Arabian group for agricultural service, Cairo, Egypt) with the following composition; Oligosaccharid (3\%), algnic acid (5\%), phytin $(0.003 \%)$, natural growth regulators (cytokinine 0.001 , indole acetic acid $0.002 \%$ and pepsin $0.02 \%$ ) and minerals (potassium oxide $12 \%$, phosphorus oxide $0.5 \%, \mathrm{~N} 1 \%$, Zn $0.3 \%$, Fe $0.2 \%$ and Mn $0.1 \%)$.

\section{Vermiwash extract}

Vermiwash was extracted from vermicompost through vermiwash collecting device. This device consists of $5 \mathrm{~L}$ container with a tap at the bottom, with the bottom of container filled with gravel (about 10 $\mathrm{cm}$ thickness), and followed by sand layer (2 to $3 \mathrm{~cm}$ thickness). Organic waste with heavy population of earth worms was filled into the container and fresh water was continually added from top. The watery yellowish to black was extracted vermiwash drainage out from bottom tap and collected up to 2 days of extraction (Ismail 1993, 1997, 2005).

\section{Experimental design and conditions}

This short term study was carried out in the green house of Pomology Dept., National Research Centre, Giza, Egypt. The experiment was performed during two successive seasons (2015 and 2016) using two years old seedlings of lemon (Citrus aurantifolia). As possible, uniform vigor with 50 to $60 \mathrm{~cm}$ height seedlings were planted on the $1^{\text {st }}$ March-2015 in $50 \mathrm{~cm}$ diameter plastic pots (one plants/pot). Each pot was filled with $20 \mathrm{~kg}$ sandy soil and irrigated inappropriate intervals. Foliar sprays of the three bio extracts under investigation were realized in seedlings at three intervals 2 weeks. Three different extract concentrations were tested; 1, 2 and $3 \%$ for yeast and algal extracts and 10, 20 and $30 \%$ for vermiwash. The treatment control was composed by sprayed with water as foliar fertilization. All treatments were applied in triplicates and the complete randomized block design was used to arrange treatments.

\section{Measurements}

\section{Vegetative growth}

At the end of each growing stage, leaf samples were collected to determine parameters related to vegetative growth i.e. leaf fresh weight, leaf dry weight (gram) while and leaf area in $\left(\mathrm{cm}^{2}\right)$. The following equation was used to calculate leaf area (Ahmed and Morsy, 1999): 
Leaf area $\left(\mathrm{cm}^{2}\right)=0.70 \times($ leaf length $\times$ leaf width $)-1.06$

\section{Leaf mineral content}

Leaf $\mathrm{N}, \mathrm{P}$ and $\mathrm{K}$ contents as percentages in dry matter were determined in leaves samples during both seasons. The dry vegetal material was digested according to the methods described by Chapman and Pratt (1978) to measure macronutrient contents. Nitrogen was determined using the Kjeldahl method, phosphorus by spectrophotometrically measured according to the method described by Jackson (1986). K, Ca and Mg were analyzed by using Perkin-Elmer (1100 B) atomic absorption spectrometer; while $\mathrm{Ca}$ and $\mathrm{Mg}$ were determined using the method outlined by Wilde et al. (1985). Total chlorophyll content was determined in fresh leaves using Minoltameter SPAD-502.

\section{Measurement of soil microbial activities}

In this study, the total microbial activities in soil were measured and presented as the releases of fluorescein due to hydrolysis of fluorescein diacetate (FDA). The analysis was performed according to the method described by Green et al. (2006) with some modifications. In brief; $5 \mathrm{~g}$ of air-dried soil (sandy soil) were placed in conical flask $(150 \mathrm{ml})$ with $50 \mathrm{ml}$ of sodium phosphate buffer $(60$ $\mathrm{mM}, \mathrm{pH} 7.6)$ and $0.5 \mathrm{ml}$ of FDA substrate solution $(4.9 \mathrm{mM}$ in acetone). After stoppering flasks, they were incubated with shaking for $2 \mathrm{~h}$ at $37^{\circ} \mathrm{C}$. To stop enzymatic FDA hydrolysis, $2 \mathrm{ml}$ of acetone were added and mixed. Around $30 \mathrm{ml}$ of suspension were transferred and centrifuged in $50 \mathrm{ml}$ falcon tubes at $6000 \mathrm{rpm}$ for 10 min. The supernatant was measured using spectrophotometer at wavelength of $490 \mathrm{~nm}$ (after filtration using a Whatman No. 1 filter paper). The control sample was performed with only $0.5 \mathrm{ml}$ of acetone instead of FDA. After, a standard curve of fluorescein was used for calculation of released fluorescein.

\section{Statistical Analysis}

Duncan's multillerange test was used to differentiate means of obtained data as described by Duncan (1955).

\section{RESULTS AND DISCUSSION}

\section{Vegetative growth measurements}

The effects of different natural extracts (algae, yeast and vermiwash) at different levels as foliar fertilizers on some vegetative growth parameters of citrus lemon seedless during two seasons were shown in Table 1. Despite no significant variation in leaf fresh weight between most treatments as response to foliar fertilization, $2 \%$ algal extract gave the highest values during both seasons $(0.49$ and $0.50 \mathrm{~g})$. Yeast extract at $1 \%$ also enhanced leaf fresh weight in both seasons $(0.48$ and $0.48 \mathrm{~g})$ as compared with the other used treatments and the control. High doses of Vermiwash (20 and $30 \%$ ) came close to the best result of algal and yeast extracts without significant differences, while treatment with $10 \%$ vermiwash recorded non-significant value lower than control.

Significant variations were recorded in leaf dry weight after the application of 1,2 and $3 \%$ yeast extract comparing to control. The highest values were obtained with $1 \%$ yeast extract followed by 2 and $3 \%$. It worth to mention that vermiwash at high dose $(30 \%)$ was improved leaf dry weight in comparison to control treatment and didn't recoded a markedly differences with best results those obtained by yeast extract at $(1 \%)$ and algae at $(2 \%)$.

On the contrary, the greatest leaf area was observed in plants sprayed with yeast extract at $2 \%$ and vermiwash at $20 \%$, which showed $(31.30$ and $31.00 \mathrm{~cm})$ and $(31.67$ and $31.80 \mathrm{~cm})$ area per leaf during $(2016$ and 2017 seasons) respectively. Generally, spraying algal extract at $2 \%$ or yeast extract at $1 \%$ as well as Vermiwash at $20 \%$ or $30 \%$ treatments were the most effective treatment regarding fresh and dry leaf weight without markedly differences between these treatments. Meanwhile, spraying yeast extract at $2 \%$ or vermiwash at $10 \%$ were the most effective in increasing leaf area in both seasons. The obtained results are agreed with the finding of Abd El-Migeed et al. (2004) on olive, Abd-El-Moniem and Abd-Allah (2008) on grape vines and Spinelli et al. (2009) on apple. They concluded that foliar spraying with natural extracts (Algae and Yeast) enhances growth performance in different orchards. In addition, Hatti et al. (2010) and Elumalai et al. (2013) verify that, foliar spraying with vermiwash increased vegetative growth parameters due to its macro and micronutrients rich contents (Palanichamy et al., 2011; Sundaravadivelan et al., 2011; Quaik et al., 2012; Manyuchi et al., 2013). Positive impacts of vermiwash may be referred to its highly contents of sugars, amino acid, phenols and plant growth promoting hormones such as humic acid and indole acetic acid which may play vital role in stimulating growth of seedlings besides serving as bio-pesticide.

\section{Leaf mineral content}

Table 2 shows the effect of natural extracts (algae, yeast and vermiwash) on leaf mineral content of citrus lemon seedlings during the examined two seasons.

In regard to chlorophyll measurements, applying most natural extractions enhanced chlorophyll content in leaves. Whereas, the highest chlorophyll content was recorded with yeast extract at 3\% (65.99 and 65.49 for both seasons respectively). Also, applying vermiwash at 20 and $3 \%$ produced chlorophyll values similar to those obtained with yeast extract at 3\% without markedly differences among these treatments. On the other hand, algae extract did not effect on chlorophyll content in comparison to control treatment.

In respect for nitrogen content, data in Table 2 indicates that algae extract at 2 and 3\% enhanced nitrogen content comparing with control treatment. Other treatments recorded a noticeable difference comparing with control treatment.

In respect to phosphorus content, obtained results 
Table 1. Influence of foliar fertilization with different natural extracts (Algae, yeast and vermiwash) at different concentrations on some vegetative growth parameters of citrus lemon seedlings during two seasons.

\begin{tabular}{|c|c|c|c|c|c|c|}
\hline \multirow{2}{*}{$\begin{array}{l}\text { Parameters } \\
\text { season treatment }\end{array}$} & \multicolumn{2}{|c|}{ Leaf fresh weight $(\mathrm{g})$} & \multicolumn{2}{|c|}{ Leaf dry weight (g) } & \multicolumn{2}{|c|}{ Leaf area $\left(\mathrm{cm}^{2}\right)$} \\
\hline & 2016 & 2017 & 2016 & 2017 & 2016 & 2017 \\
\hline Control & $0.41^{\mathrm{bc}}$ & $0.44^{\mathrm{abc}}$ & $0.13^{d}$ & $0.13^{d}$ & $26.10^{\mathrm{cd}}$ & $23.50^{\text {de }}$ \\
\hline Algae extract $1 \%$ & $0.43^{\mathrm{abc}}$ & $0.44^{\mathrm{abc}}$ & $0.15^{\mathrm{cd}}$ & $0.15^{\mathrm{cd}}$ & $21.00^{\mathrm{e}}$ & $20.67^{e}$ \\
\hline Algae extract $2 \%$ & $0.49^{\mathrm{a}}$ & $0.50^{\mathrm{a}}$ & $0.18^{\mathrm{ab}}$ & $0.19^{a}$ & $20.68^{e}$ & $21.00^{\mathrm{e}}$ \\
\hline Algae extract $3 \%$ & $0.44^{\mathrm{abc}}$ & $0.46^{\mathrm{abc}}$ & $0.14^{\mathrm{cd}}$ & $0.15^{\mathrm{cd}}$ & $30.00^{\mathrm{ab}}$ & $30.17^{\mathrm{ab}}$ \\
\hline Yeast extract 1\% & $0.48^{\mathrm{ab}}$ & $0.48^{\mathrm{ab}}$ & $0.19^{a}$ & $0.19^{a}$ & $26.67^{\mathrm{bcd}}$ & $26.67^{\mathrm{bcd}}$ \\
\hline Yeast extract 2\% & $0.44^{\mathrm{abc}}$ & $0.46^{\mathrm{abc}}$ & $0.16^{\mathrm{abc}}$ & $0.17^{\mathrm{abc}}$ & $31.30^{\mathrm{a}}$ & $31.00^{\mathrm{a}}$ \\
\hline Yeast extract 3\% & $0.46^{\mathrm{abc}}$ & $0.44^{\mathrm{abc}}$ & $0.16^{\mathrm{abc}}$ & $0.17^{\mathrm{abc}}$ & $23.50^{\text {de }}$ & $26.17^{\mathrm{cd}}$ \\
\hline Vermiwash $10 \%$ & $0.39^{c}$ & $0.38^{c}$ & $0.13^{d}$ & $0.14^{C D}$ & $31.67^{\mathrm{a}}$ & $31.08^{a}$ \\
\hline Vermiwash $20 \%$ & $0.44^{\mathrm{abc}}$ & $0.45^{\mathrm{abc}}$ & $0.14^{\mathrm{cd}}$ & $0.16^{\mathrm{abc}}$ & $26.25^{\mathrm{cd}}$ & $28.75^{\mathrm{abc}}$ \\
\hline Vermiwash $30 \%$ & $0.42^{\mathrm{abc}}$ & $0.44^{\mathrm{abc}}$ & $0.17^{\mathrm{abc}}$ & $0.18^{\mathrm{ab}}$ & $28.76^{\mathrm{abc}}$ & $26.25^{\mathrm{cd}}$ \\
\hline
\end{tabular}

Means followed by the same letter(s) with each parameter are not statistically different $5 \%$ level.

Table 2. Effect on natural extracts (algae, yeast and vermiwash) on leaf mineral content of citrus lemon seedlings during 2016 and 2017 seasons.

\begin{tabular}{|c|c|c|c|c|c|c|c|c|c|c|c|c|}
\hline \multirow{2}{*}{$\begin{array}{l}\text { Leaf mineral content } \\
\text { Season treatment }\end{array}$} & \multicolumn{2}{|c|}{ Chlorophyll (spad) } & \multicolumn{2}{|c|}{ Nitrogen $\%$} & \multicolumn{2}{|c|}{ Phosphorus \% } & \multicolumn{2}{|c|}{ Potassium \% } & \multicolumn{2}{|c|}{ Calcium \% } & \multicolumn{2}{|c|}{ Magnesium \% } \\
\hline & 2016 & 2017 & 2016 & 2017 & 2016 & 2017 & 2016 & 2017 & 2016 & 2017 & 2016 & 2017 \\
\hline Control & $57.82^{\mathrm{C}}$ & $57.63^{\mathrm{C}}$ & $1.79^{\mathrm{bc}}$ & $1.92^{b c}$ & $0.19^{\text {def }}$ & $0.18^{\text {def }}$ & $2.76^{d}$ & $2.93^{\mathrm{cd}}$ & $1.76^{a}$ & $2.30^{\mathrm{a}}$ & $0.21^{d}$ & $0.20^{d}$ \\
\hline Algae extract $1 \%$ & $57.33^{c}$ & $57.63^{c}$ & $1.93^{\mathrm{bc}}$ & $1.78^{\mathrm{bc}}$ & $0.23^{\text {cde }}$ & $0.23^{\text {cde }}$ & $2.93^{\mathrm{cd}}$ & $2.77^{d}$ & $2.30^{\mathrm{a}}$ & $2.13^{\mathrm{a}}$ & $0.28^{\mathrm{cd}}$ & $0.29^{\mathrm{cd}}$ \\
\hline Algae extract $2 \%$ & $57.63^{\mathrm{c}}$ & $57.33^{c}$ & $2.19^{b}$ & $2.20^{\mathrm{b}}$ & $0.14^{\mathrm{fg}}$ & $0.15^{f}$ & $3.04^{c}$ & $3.03^{c}$ & $2.13^{\mathrm{a}}$ & $1.67^{\mathrm{a}}$ & $0.32^{\mathrm{bc}}$ & $0.33^{b c}$ \\
\hline Algae extract $3 \%$ & $59.83^{\mathrm{bc}}$ & $59.0^{\mathrm{bc}}$ & $2.19^{b}$ & $2.19^{b}$ & $0.22^{\text {cdf }}$ & $0.20^{\text {cdf }}$ & $3.04^{c}$ & $3.03^{c}$ & $1.73^{\mathrm{a}}$ & $1.67^{\mathrm{a}}$ & $0.27^{\mathrm{cd}}$ & $0.23^{\mathrm{cd}}$ \\
\hline Yeast extract $1 \%$ & $58.83^{c}$ & $58.0^{c}$ & $1.71^{b c}$ & $1.70^{\mathrm{bc}}$ & $0.31^{\mathrm{b}}$ & $0.30^{\mathrm{b}}$ & $3.59^{b c}$ & $3.60^{\mathrm{bc}}$ & $2.10^{\mathrm{a}}$ & $2.00^{\mathrm{a}}$ & $0.44^{\mathrm{a}}$ & $0.45^{\mathrm{a}}$ \\
\hline Yeast extract $2 \%$ & $59.83^{c}$ & $59.82^{\mathrm{bc}}$ & $1.45^{\mathrm{c}}$ & $1.46^{\mathrm{c}}$ & $0.15^{f}$ & $0.14^{f}$ & $3.5^{\mathrm{c}}$ & $3.59^{b c}$ & $1.53^{\mathrm{a}}$ & $1.67^{\mathrm{a}}$ & $0.32^{\mathrm{bc}}$ & $0.36^{b c}$ \\
\hline Yeast extract $3 \%$ & $65.99^{a}$ & $65.49^{a}$ & $1.38^{\mathrm{c}}$ & $1.40^{c}$ & $0.25^{\mathrm{bc}}$ & $0.26^{\mathrm{bc}}$ & $3.67^{\mathrm{bc}}$ & $3.00^{c}$ & $2.18^{a}$ & $2.13^{\mathrm{a}}$ & $0.39^{a b}$ & $0.40^{a b}$ \\
\hline Vermiwash $10 \%$ & $63.33^{\mathrm{ab}}$ & $63.34^{\mathrm{b}}$ & $1.89^{\mathrm{bc}}$ & $1.89^{b}$ & $0.18^{\text {ef }}$ & $0.17^{\text {ef }}$ & $4.41^{\mathrm{a}}$ & $4.36^{a}$ & $1.87^{\mathrm{a}}$ & $2.00^{a}$ & $0.31^{\mathrm{bc}}$ & $0.31^{b c}$ \\
\hline Vermiwash $20 \%$ & $61.44^{\mathrm{abc}}$ & $61.33^{\mathrm{abc}}$ & $2.12^{b}$ & $2.19^{b}$ & $0.24^{\mathrm{cb}}$ & $0.23^{\mathrm{cb}}$ & $4.35^{\mathrm{a}}$ & $4.40^{\mathrm{a}}$ & $2.05^{\mathrm{a}}$ & $2.03^{a}$ & $0.29^{\mathrm{cd}}$ & $0.21^{\mathrm{cb}}$ \\
\hline Vermiwash $30 \%$ & $61.33^{\mathrm{ab}}$ & $65.50^{\mathrm{a}}$ & $2.74^{\mathrm{a}}$ & $2.75^{\mathrm{a}}$ & $0.42^{\mathrm{a}}$ & $0.43^{\mathrm{a}}$ & $4.02^{a}$ & $4.03^{a}$ & $1.48^{a}$ & $2.00^{\mathrm{a}}$ & $0.28^{\mathrm{cd}}$ & $0.29^{\mathrm{cd}}$ \\
\hline
\end{tabular}

Means followed by the same letter(s) with each parameter are not statistically different $5 \%$ level.

show that applying vermiwash at $30 \%$ enhanced phosphorus content in leaves whereas the highest value of $P(0.42$ and 9.43 in two seasons respectively) was recorded with vermiwash at $30 \%$ comparing with other treatments.
For potassium content, data in Table 2 reveal that vermiwash treatments surpassed all tested treatments in producing high potassium content. Meanwhile, yeast extract treatments came in second rank after vermiwash treatments. The lowest value of potassium content was recorded with control treatment.

The trend in nutrient content was differed in calcium case whereas results didn't show significantly differences among different 
treatments.

For magnesium content both of yeast extract at 1 and $3 \%$, treatments resulted increasing $\mathrm{Mg}$ content in leaves comparing with other treatments. However, the lowest $\mathrm{Mg}$ content recorded with control treatment during two seasons.

In general, treatments with different natural extracts promoted an increase in the nutrient contents of the citrus lemon seedlings except in the $\mathrm{Ca}$ case, when compared with the control treatment. But, almost no significant differences in mineral contents were observed between the two recorded seasons. The results observed after the applications with vermiwash at different concentrations $(10,20$ and $30 \%)$ were that most induced an increase in most leaf nutrient content compared with that of the control and algal and yeast extracts.

These results are, in general, agreed with the findings of Abul-Soud et al. (2009) and Xing et al. (2010) who referred that, earthworm casting (vermicompost and its products) is a nutritive organic fertilizer rich in humus, $\mathrm{N}$, $\mathrm{P}, \mathrm{K}$ and micronutrients, which is beneficial to increase soil microbial activity and the solubility of the phosphate. Also, they indicated that earthworm casting contains important growth hormones like auxins, gibberellins and cytokines. Moreover, Xing et al. (2010) proved that vermicompost and vermiwash could be used as growth promoters and protectors for crop development. Vermicompost and vermiwash are sustainable fertilizers which can be quickly produced since worm multiplies by themselves (Xing et al., 2010).

\section{Microbial activities of soil in response to different foliar fertilizers}

Short term applications of either microalgal extract, yeast extract and vermiwash at previously mentioned application doses seemed to influence total microbial activities of citrus' rhizosphere under investigation. After the first one-third of cultivation period, the microbial activities on the citrus's rhizosphere showed quick response to the foliar fertilization. As presented in Figure $1 \mathrm{a}$, the highest microbial activity was recorded with application of $3 \%$ yeast extract. Its value was around three times more than control treatment.

The application of algal extract foliar fertilizer also showed relatively increase in soil microbial activity, in more than 1.5 times, in comparing to the control and higher algal extract concentrations (2 and $3 \%$ ).

The three used concentrations of vermiwash reflected moderate activities comparing to algae and yeast extracts. After the second-third period of cultivation, the total microbial activities increased with almost all treatments with similar manner including control, except on the highest concentration of vermiwash. In this case, the application of $30 \%$ vermiwash as foliar fertilization showed higher activity for the citrus rhizosphere microorganisms (Figure 1b).
At the end of the short term-study (24 weeks), the total microbial activities showed different values. The highest microbial activities were recorded with foliar fertilization using algal extracts (at all three tested concentrations).

Despite foliar application of yeast found to be in the second order after algal extract, it was higher than application of vermicompost regarding microbial activity of soil.

The obtained results supported what was mentioned by Grzesik et al. (2017) who showed that, the foliar biofertilization under the conditions of limited use of chemical fertilizers is known to influence the photosynthetic performance and growth of plants. As the nutritional status of plants affects its growth, it also influences root exudates and microbial activity of the soil (Grayston et al., 1997). FDA is known to be hydrolyzed due to the actions of several common enzymes in soil microorganisms which reflects the total microbial activities of the soil (Schnürer and Rosswall, 1982). Rhizosphere microflora have a synergistic relation with plants through microbial activity and plant root exudates (Bashir et al., 2016).

According to Ahmed et al. (2011), yeast extract is considers good foliar fertilization due to its contents of vitamins and aminoacids. For this, it has positive influence regarding plant growth parameters of their studied plants.

Microalgal extracts are known to contains substances that promote the enhance plant growth as well as its root exudates. Also, it is rich in macro and micronutrients that benefits plants either by foliar or soil applications (Renuka et al., 2017).

In a related study, Khan et al. (2014) reported that using vermiwash as foliar fertilization modifies the interaction response of studied plant to some beneficial microorganisms (arbuscular mycorrhizal fungi in such case). The results found in this study may also explain the dynamic changes different in soil microbial activities in response to foliar vermiwash application reported in this study.

Generally, short term application of fertilizers demonstrated to cause different changes in the structure of soil microbial community as well as its total activity and function (Lazcano et al., 2013). Those facts are agreed with our current data regarding the different microbial activities in rhizosphere response to studied short term foliar fertilizations.

\section{CONCLUSION}

Natural extracts of algae, yeast and vermiwash are considered as promising foliar fertilization for citrus lemon seedlings. The foliar application with yeast extract has the ability to influence vegetative growth parameter of fertilized plants. Vermiwash was superior in enhancing mineral contents in leaves comparing with algal and yeast extract. Microbial activity of rhizosphere was 

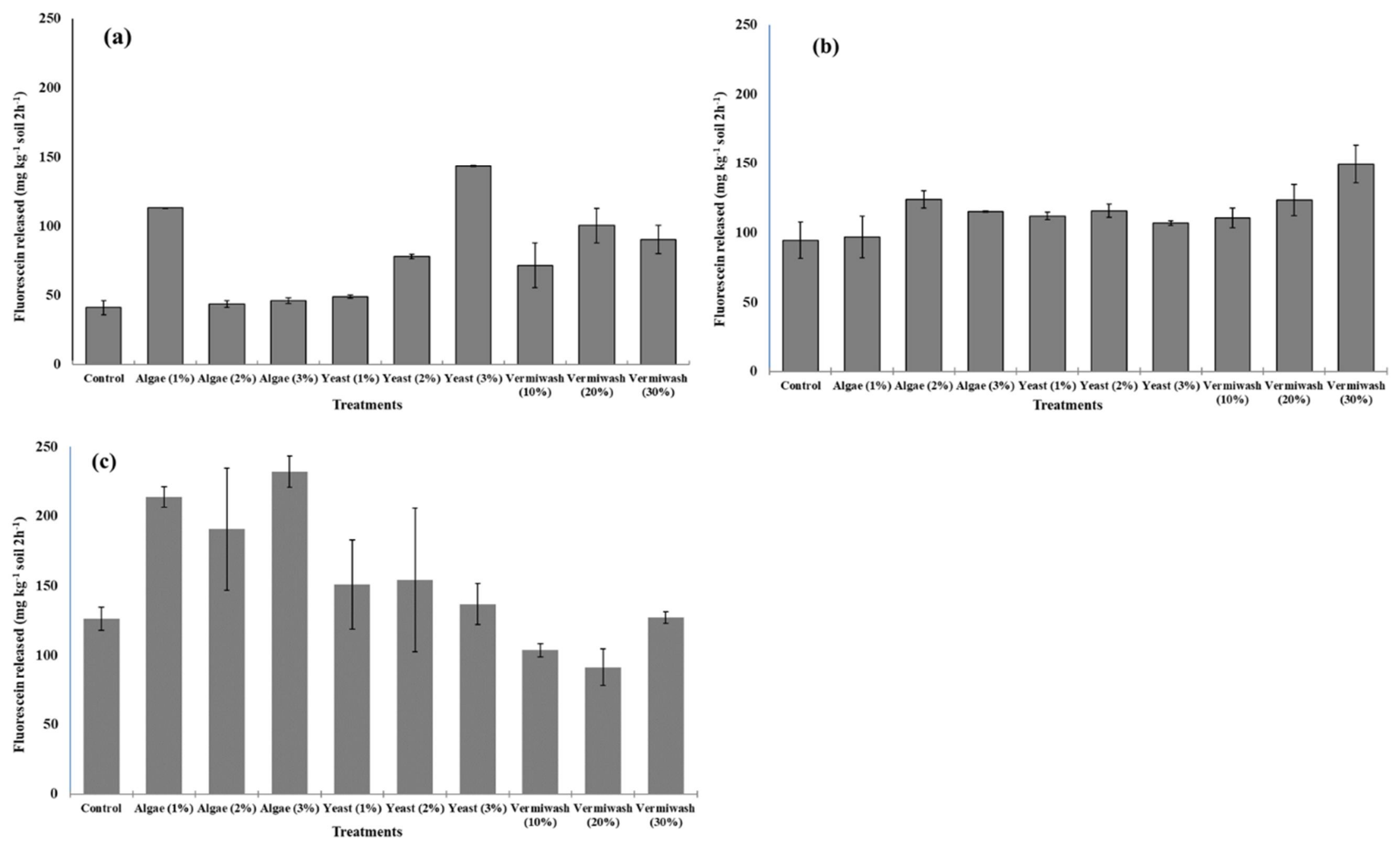

Figure 1. Total microbial activities in citrus (Lime) rhizosphere soil represented as FDA release ( $\left.\mathrm{mg} \mathrm{kg}^{-1} \mathrm{soil}^{2} \mathrm{~h}^{-1}\right)$ in response to different foliar fertilization after the first one-third (a), two-third (b) and at the end (c) of cultivation period.

affected by nutritional status of plants. Algal extract as foliar fertilization could enhance soil microbial activity due to plant root exudates.

\section{REFERENCES}

Abd El-Migeed AA, El-Sayed AB, Hassan HAS, 2004. Growth enhancement of olive transplants by broken cells of fresh green algae as soil application. J Agric Res, 29(3): 723-737. Abd-El-Moniem EA, Abd-Allah ASF, 2008. Effect of green algae cell extract as folia spray on vegetative growth, yield and berries quality of superior grape vines. Ann Euras J 
Agric Environ,Sci, 4: 427-433.

Abobatta W, 2018. Improving Navel orange (Citrus sinensis L) productivity in Delta Region, Egypt. Adv Agr Environ Sci, 1(1): 36-38.

Abou El-Yazied A, Mady MA, 2012. Effect of boron and yeast extract foliar application on growth pod setting and both green pod and seed yield of broad bean (Cicia faba L). J App Sci Res, 8(2): 1240-1251.

Abul-Soud M, Hassanein MK, Ablmaaty SM, Medany M, Abu-Hadid $A F$, 2009. Vermi culture and vermi composting technologies use in sustainable agriculture in Egypt. Egypt J Agric Res, 87(1): 389-401.

Ahmed AA, El-Baky MA, Zaki MF, El-Aal FSA, 2011. Effect of foliar application of active yeast extract and zinc on growth, yield and quality of potato plant (Solanum tuberosum L.). J Appl Sci Res, 7(12): 2479-2488.

Ahmed FF, Morsy MH, 1999. A new method for measuring leaf area in different fruit species. Minia J Agric Dev. pp. 97-105.

Barnett JA, Payne E, Diyarrow, 1990. Yeast Characteristics and Identification. $2^{\text {nd }}$ ed. Cambride Univ. Press.

Bashir O, Khan K, Hakeem KR, Mir NA, Rather GH, Mohiuddin R, 2016. Soil microbe diversity and root exudates as important aspects of rhizosphere ecosystem. In Plant, Soil and Microbes (pp. 337-357). Springer, Cham.

Chapman HD, Pratt PE, 1978. Method of analysis for soil plant and water. University of California, Department of Agriculture Science. U.S.A.: 1-309.

Duncan DB, 1955. Multiple range and multiple $F$ test. Biometrics, 11: 142.

Eida MF, Darwesh OM, Matter IA, 2018. Cultivation of Oleaginous microalgae Scenedesmus obliquus on secondary treated municipal wastewater as growth medium for biodiesel production. $J$ Ecol Eng, 19: 5.

El-Sayed OM, 2013. Improvement of Aggizy olive trees productivity in saline calcareous soils using active dry yeast and humic acid. Res $\mathrm{J}$ Agric Biol Sci, 9(5): 136-144.

Elumalai D, Kaleena PK, Fathima M, Hemavathi M, 2013. Influence of vermiwash and plant growth regulators on the exomorphological characters of Abelnoschus esculentus (linn) Moench. Afr J Basic Appl Sci, 2: 82-90.

Grayston SJ, Vaughan D, Jones D, 1997. Rhizosphere carbon flow in trees, in comparison with annual plants: the importance of root exudation and its impact on microbial activity and nutrient availability. Appl Soil Ecol, 5(1): 29-56.

Green VS, Stott DE, Diack M, 2006. Assay for fluorescein diacetate hydrolytic activity: optimization for soil samples. Soil Biol Biochem, 38(4): 693-701.

Grzesik M, Romanowska-Duda Z, Kalaji HM, 2017. Effectiveness of cyanobacteria and green algae in enhancing the photosynthetic performance and growth of willow (Salix viminalis L.) plants under limited synthetic fertilizers application. Photosynthetica, 55(3): 510521.

Hashem M, Omran Y, Sallam MN, 2008. Efficacy of yeasts in the management of root-knol nematode (Meliodogyne incognita) in flame seedless grape vines and the consequent and the productivity of the vines. Biocontrol Sci Technol, 18(4): 357-375.

Hatti SS, Londonkar RL, Patil SB, Gangawane AK, Patil CS, 2010. Effect of Eisenia fetida verniwash on the growth plants. J Crop Sci, 1: 6-10.

Ismail SA, 1993. Keynote Papers and Extended Abstracts. Congress on traditional Sciences and Technologies of India, H.T., Mumbai, 10: 27-30.

Ismail SA, 1997. Vemicology. The Biology of Earthworms, Drient Longman Press, Hyderabad, pp 92.

Ismail SA, 2005. The Earthworm Book. Other India Press, Mapusa, Goa. pp.92

Jackson ML, 1986. Soil Chemical Analysis, 251-280.Printice Hall, Indian Private Limited, New Delhi.

Jandaik S, Kumar V, Thakur P, 2015. Vermiwash: Plant growth enhancer and antifungal agent. Int J Extensive Res, 2: 38-41.

Kaur P, Bhardwaj M., Babbar I, 2015. Effect of vermicompost and vermiwash on growth of vegetables. Res $\mathrm{J}$ Anim Veter Fishery Sci, 3(4): 9-12.
Khan MH, Meghvansi MK, Gupta R, Veer V, Singh L, Kalita MC, 2014 Foliar spray with vermiwash modifies the arbuscular mycorrhizal dependency and nutrient stoichiometry of bhut jolokia (Capsicum assamicum). PloS one, 9(3): e92318.

Lazcano C, Gómez-Brandón M, Revilla P, Domínguez J, 2013. Shortterm effects of organic and inorganic fertilizers on soil microbial community structure and function. Biol Fertility Soils, 49(6): 723-733.

Manyuchi MM, Phiri A, Muredzi P, Boka S, 2013. Comparison of vermicompost and vermiwash bio-fertilizers from vermicomposting waste corn pulp. World Academy of Science, Engineering and Technology (submitted for publication).

Marzauk N, Safeek M, Helmy Y, Ahmed A, Shalaby M, 2014. Effect of vitamin $E$ and yeast extract foliar application on growth, pod yield and both green pod and seed yield of broad bean (Vicia faba L). Middle East J Appl Sci, 4(1): 61-67.

Matter IA, Darwesh OM, Eida MF, 2018. Harvesting of microalgae Scenedesmus obliquus using chitosan-alginate dual flocculation system. Biosci Res, 15(1): 540-548.

Nath G, Singh K, 2011. Effect of foliar spray of bio pesticides and vermiwash of animal, agro and kitchen wastes on soybean (Glycime max L.) crop. Bot Res Int, 4(3): 52-57.

Palagani N, Singh A, 2017. Influence of bio fertilizers and foliar spray of Spermine and Vermiwash on growth, yield and postharvest quality of Gerbera (Gerbera jamesonii Hook.) under naturally ventilated polyhouse. Int J Curr Microbiol Appl Sci, 6(12): 245-253.

Palanichamy V, Mitra B, Reddy N, Katiyar M, Rajkumari R, Ramalingam B, Arangantham C, 2011. Utilizing food waste by vermicomposting, extracting vermiwash, castings and increasing relative growth of plants. Int J Chem Anal Sci, 2(11): 1241-1246.

Quaik S, Embrandiri A, Rupani PF, Singh RP, Ibrahim MH, 2012. Effect of vermiwash and vermicompost leachate in hydroponics culture of Indian borage (Plectranthus ambionicus) plantlets. $11^{\text {th }}$ International Annual Symposium on Sustainability Science and Management, pp. 210-214.

Renuka N, Prasanna R, Sood A, Bansal R, Bidyarani N, Singh R, Shivay YS, Nain L, Ahluwalia AS, 2017. Wastewater grown microalgal biomass as inoculants for improving micronutrient availability in wheat. Rhizosphere, 3: 150-159.

Schnürer J, Rosswall, T., 1982. Fluorescein diacetate hydrolysis as a measure of total microbial activity in soil and litter. Appl Environmental Microbiol, 43(6): 1256-1261.

Spinelli F, Giovanni F, Massimo N, Mattia S, Guglielmo C, 2009 Perspectives on the use of a sea weed extract to moderate the negative effects. A falternate bearing in apple trees. J Hort Sci Biotechnol, 17: 131-137.

Sundaravadivelan $C$, Isaiarasu $L$, Manimuthu $M$, Kumar $P$, Kuberan $T$, Anburaj J, 2011. Impact analysis and confirmative study of 7 hysicchemical, nutritional and biochemical parameters of vermiwash produced from different leaf litters by using two earthworm species. $J$ Agric Technol, 7(5): 1443-1457.

Wilde SA, Corey RB, Glyer J, Kivaight G, 1985. Soil and plant analysis for tree culture. Mohan primlani, Oxford, IBH Publishing Co., New Delhi, pp: 1-172.

Xing M, Li X, Jian $Y$, 2010. Treatment performance of Small Scale vermi filter for domestic waste water and its relationship to earth worm growth reproduction and enzymatic activity. Afr J Biotechnol, 9(44): 7513-7520.

Citation: Mustafa NS, Matter IA, Abd alla HR, El-Dahshouri MF, Zaid NS, 2019. The promotive effects of some natural extracts (algal, yeast and vermiwash) on vegetative characteristics and nutrients status of citrus lemon (Citrus aurantifolia) seedlings. Net J Agric Sci, 7(2): 4349. 